Article

\title{
Ground-Penetrating Radar Study of Progradational Units in Holocene Coastal Plains: Carchuna Beach (SE Spain)
}

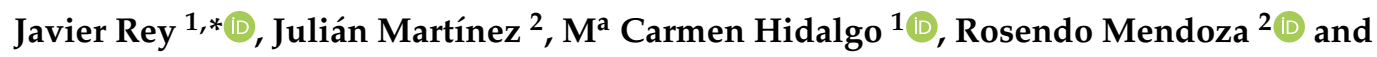 \\ $\mathbf{M}^{\mathrm{a}}$ José Campos ${ }^{1}$ \\ 1 Departamento de Geología-CEACTEMA. E.P.S. de Linares, Campus Científico Tecnológico, \\ Universidad de Jaén, 23700 Linares, Jaén, Spain; chidalgo@ujaen.es (M.C.H.); mjcampos@ujaen.es (M.J.C.) \\ 2 Departamento de Ingeniería Mecánica y Minera-CEACTEMA, EPS de Linares, \\ Campus Científico Tecnológico, Universidad de Jaén, 23700 Linares, Jaén, Spain; jmartine@ujaen.es (J.M.); \\ rmendoza@ujaen.es (R.M.) \\ * Correspondence: jrey@ujaen.es
}

Received: 4 June 2020; Accepted: 17 July 2020; Published: 19 July 2020

check for updates

\begin{abstract}
The internal geometries of progradational units on the coastal plain in southeastern Spain (Carchuna Beach, Granada) since the maximum Holocene marine transgression (ca. $7000 \mathrm{cal} \mathrm{BP}$ ) have been analysed using ground-penetrating radar (GPR). Radargram analysis shows the presence of sedimentary structures consistent with the progradation of coastal plains, interpreted as laminations associated with the foreset and topset. Laterally, five middle scale progradational units ( $\mathrm{H} 2, \mathrm{H} 3, \mathrm{H} 4$, $\mathrm{H} 5$ and $\mathrm{H} 6$ ) are identified. Each of these units can be grouped into two major units. The general trend towards progradation is interrupted at the boundary of the units. Minor scale units (prograding wedges), deposited at topographically lower areas, are detected in GPR profiles. The radargrams also show channel erosional surfaces and sigmoidal landward dipping reflections interpreted as washover channel deposits, with the erosion and transference of sediments between the beach and the back-ridge domain. Furthermore, the saturation of coastline sediments with saltwater rapidly attenuates the GPR signal. Thus, the GPR is also a good tool to detect saltwater intrusions in shallow aquifers.
\end{abstract}

Keywords: coastal plain; progradational units; ground-penetrating radar; berm ridges facies; prograding radar facies; Holocene; saltwater intrusions; Spain

\section{Introduction}

Coastal accretion and erosion processes are closely related to climatic conditions, to sea level oscillations [1-3] and to anthropogenic changes [4]. In recent decades, the increase in population in coastal areas has been considerable. This entails, synchronously, the development of urban projects, the construction of infrastructures and the exploitation of natural resources, without taking into account, in many cases, coastal environmental impacts. Knowledge of current and recent coastal dynamics is a valuable tool in predicting natural risks and hazards in these coastal areas, and therefore, for sustainable development. In this regard, examining the Holocene coastal environments provides valuable information [4].

Studies conducted in the southern region of the Iberian Peninsula have identified the maximum of the Holocene marine transgression as occurring approximately 7000 years ago [5-7]. Since then, sea level oscillations have been minimal, remaining near the current level $[6,8,9]$. In this region, in Holocene highstand shallow marine deposits, Hernández Molina et al. [10] have described infralittoral prograding wedge (IPW) stages, internally characterised by a sedimentary prograding wedge with downlap in the lower boundary and toplap in the upper boundary, as well as internal downlap 
surfaces. Lobo et al. [11] studied the internal structures of these offshore deposits and suggested that there are three hierarchical patterns. They described two major units, which may correspond to those defined by Hernández-Molina et al. [10], and four intermediate and 12 minor units, which the authors correlated with progradational units. In high-resolution seismic profiles of infralittoral zones, Fernández-Salas et al. [12] observed a more complex distribution of IPWs due to the lateral deposition of individual prograding wedges related to longshore transport. These bodies result from the accumulation of small sedimentary units that would reflect minor sea-level fluctuations.

Conversely, in adjacent coastal plains, prograding bodies have also been described for this time interval. Thus, in zones with an adequate sediment input, two phases of coastal progradation occurred, separated by an erosional gap that dates back to approximately 2400 years ago [13,14]. These bodies are correlated with the two major units described by Lobo et al. [11] in offshore zones. They described three progradational units in the first unit (H1, H2 and H3, sensu Goy et al. [9] and three others in the second unit (H4, H5 and H6 sensu Goy et al. [9]). The bases of these units (H2, H3, H4, H5 and H6, respectively) have been dated to 5400, 4200, 2700, 1900 and 500 years before present (BP), respectively, in studies conducted by Zazo et al. [6] on the Mediterranean coast.

Carchuna Beach, in the province of Granada (SE Spain, Figure 1), has been one of the outcrops on which studies of these progradational units of the coastal plain have focused [9,12-16]. This beach is $4 \mathrm{~km}$ long and is bordered to the west by Cape Sacratif and to the east by the tip of Cerro Gordo (Figure 1).

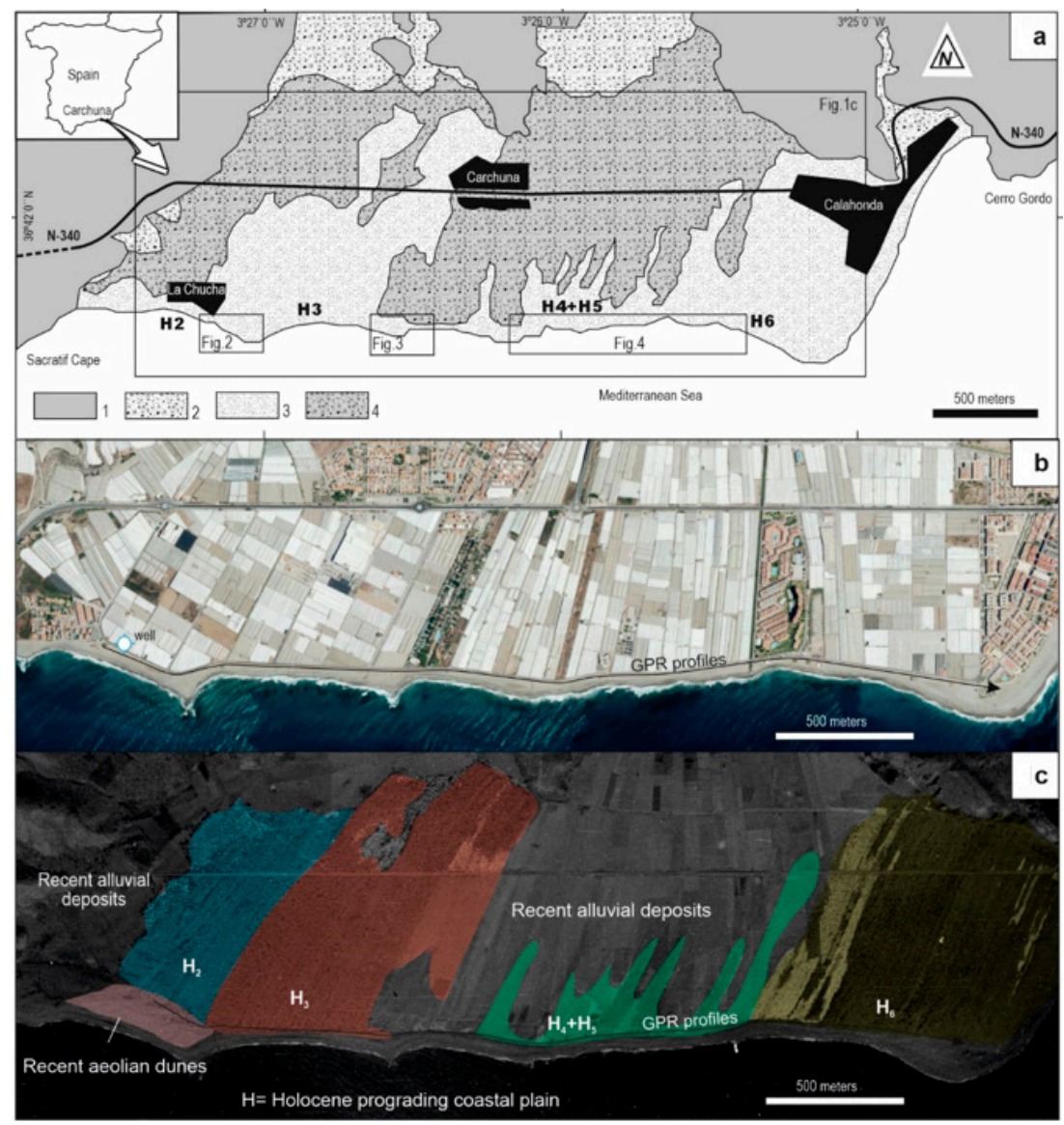

Figure 1. Geological location of the studied sector from [16]. 1. Paleozoic and Triassic basement. 2. Pleistocene alluvial fans. 3. Recent alluvial deposits. 4. Holocene prograding coastal plain (H2, H3, H4, H5: prograding units sensu Goy et al. [9]) (a). Recent aerial photograph of the studied area. Human activity does not allow us to observe the prograding coastal plain units (b). Aerial photograph of the studied area in 1946. The Holocene prograding coastal plain units (H2, H3, H4, H5 and H6) described [12] have been superimposed (c). 
Geologically, two sets can be differentiated in the sector: an underlying metamorphic basement and an overlying sedimentary cover, which is the current coastal plain. The metamorphic basement (1 in Figure 1) forms part of the Alpujárride Complex of the Internal Zones of the Betic Cordillera and consists of Palaeozoic schists, Permian-Triassic phyllites and Triassic marbles [17]. In the detritic sediments of the overlying sedimentary cover, three units are differentiated: on the one hand, the mappable conglomerate deposits in the north zone and at the bottom of the gullies ( 2 in Figure 1$)$ are interpreted as alluvial deposits of Pleistocene-Middle Holocene age [17]; on the other hand, to the south, in the coastal zone, sand and gravel facies of Holocene age are associated with progradational units of the coastal plain [12-14] (3 in Figure 1). Based on photointerpretation and ${ }^{14} \mathrm{C}$ dating [13,14] Goy et al. [9] suggest that these structures were generated after the maximum Holocene transgression and that up to five of the six progradational units described in the SE of the Iberian Peninsula are separated from each other by small erosion episodes (H2, H3, H4, H5 and H6 in Figure 1).

One of the characteristics of this beach is that it is not associated with the mouths of rivers with significant sedimentation rates. In fact, the sedimentary contribution is related to regional coastal drift towards the west-southwest from the Adra River [14]. Another noteworthy characteristic of this beach is the barrier that Cape Sacratif forms, which determines the eastward formation of the aforementioned progradational units $[13,14]$.

Despite previous studies on this beach, the internal morphology of these bodies has not been described due to the poor quality of the outcrops, which are partly covered by more recent alluvial deposits (4 in Figure 1a) and by the current greenhouses (Figure 1b). Thus, this study aims to characterise the internal structure of these coastal deposits and to analyse in detail the morphologies of the sedimentary bodies in the boundaries of these middle scale units (Figure 1c). This study will provide new information on events during the Holocene age defined in the literature in SE Spain.

Our study uses ground-penetrating radar (GPR). This geophysical prospecting method has already been successfully used to characterise the internal structures of sedimentary bodies, particularly the internal structure of coastal units [18-25]. Therefore, we propose that GPR is an appropriate and useful tool in this case.

\section{Material and Methods}

GPR was used as a geophysical survey method. It is a non-destructive method based on the study of high-frequency electromagnetic wave propagation in the subsurface. Penetration depth and resolution depend on the electromagnetic properties of the soil materials and on the frequency of the electromagnetic signal emitted by the antenna used: high-frequency antennas provide high resolution and low penetration depth, whereas low-frequency antennas provide low resolution and high penetration depth [26,27].

The ground-penetrating radar used in this study was the RAMAC/GPR system, model Pro-Ex, manufactured by MALA GEOSCIENCE (http://www.malags.com/home). GPR profiles were acquired using 100-MHz and 250-MHz shielded antennas (Figures 2-4) in these progradational units, next to the current beach (Figure 1c).

The GPR data acquisition software Ground Vision (http://www.ingeodav.fcen.uba.ar/Curso/ prospeccion\%20geofisica/Martingarcia/Georradar/GroundVision\%20Manual.pdf) was used in this study because it allows us to set, for each recording, the measurement parameters, including the antenna frequency, time window, sampling frequency or the zero time of the profile. Thus, sampling frequencies of $1089 \mathrm{MHz}$ and $2540 \mathrm{MHz}$ were used for the 100-MHz and 250-MHz antennas, respectively, with a 426.9-189.8 $\mathrm{ns}$ time window (512 samples per profile) and with a $0.03 \mathrm{~m}$ profile interval.

In total, 67 profiles were recorded, totalling $4500 \mathrm{~m}$. In this study, seven profiles were selected to provide an overview of the distribution of sedimentary bodies in this coastal plain. The position of each unit is shown in Figure 1. The radargrams, and their respective locations, are shown in Figures 2-4. 


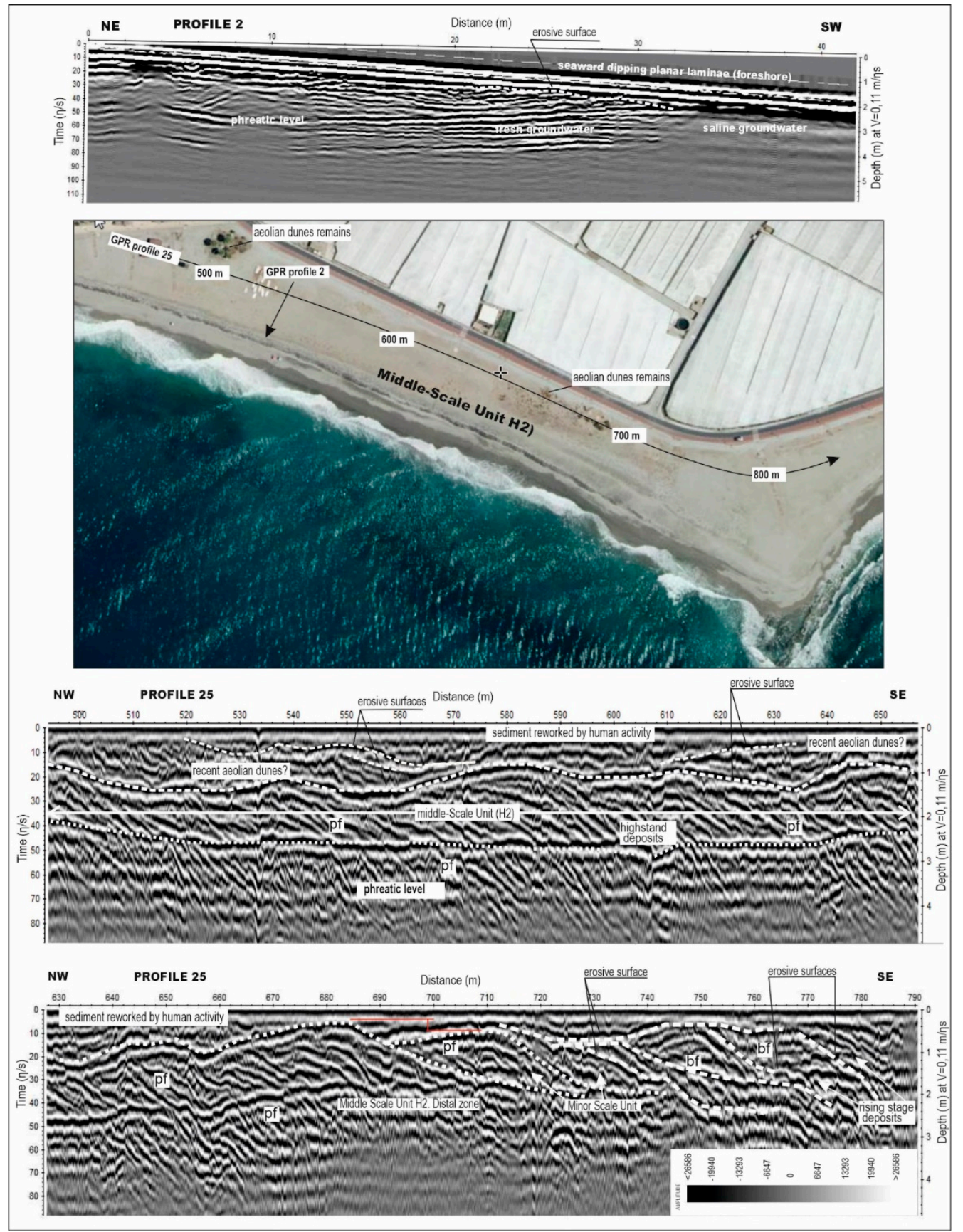

Figure 2. Radargrams obtained using a 250-MHz antenna frequency in unit 2, perpendicular (profile 2) and parallel (profile 25) to the coastline. The geometry and vertical position of the minor units indicate small sea-level falls (see red line). pf: prograding radar facies; bf: berm ridge radar facies.

The signal recorded in the field was processed using the software Reflexw [Sandmeier, K. J. REFLEXW Version 7.0]. First, time zero (first arrival of a radar wave) was adjusted using the static correction filter "move startime" (9 $\mathrm{ns}$ for the $100-\mathrm{MHz}$ antenna and $15 \mathrm{\eta s}$ for the $250-\mathrm{MHz}$ antenna). In profiles perpendicular to the coastline, with an elevation difference greater than one metre, the topography was corrected using the options "3D-topography" and "topography migration". In profiles parallel to the coastline, with minimal grade difference, these corrections were unnecessary. The filter "subtract DC shift" was used to remove residual voltage, and the filter "subtract mean" (dewow) was used to remove the direct wave. The option "automatic gain control" was selected to amplify the signal. Lastly, the filter "background removal" was used to remove background noise. 


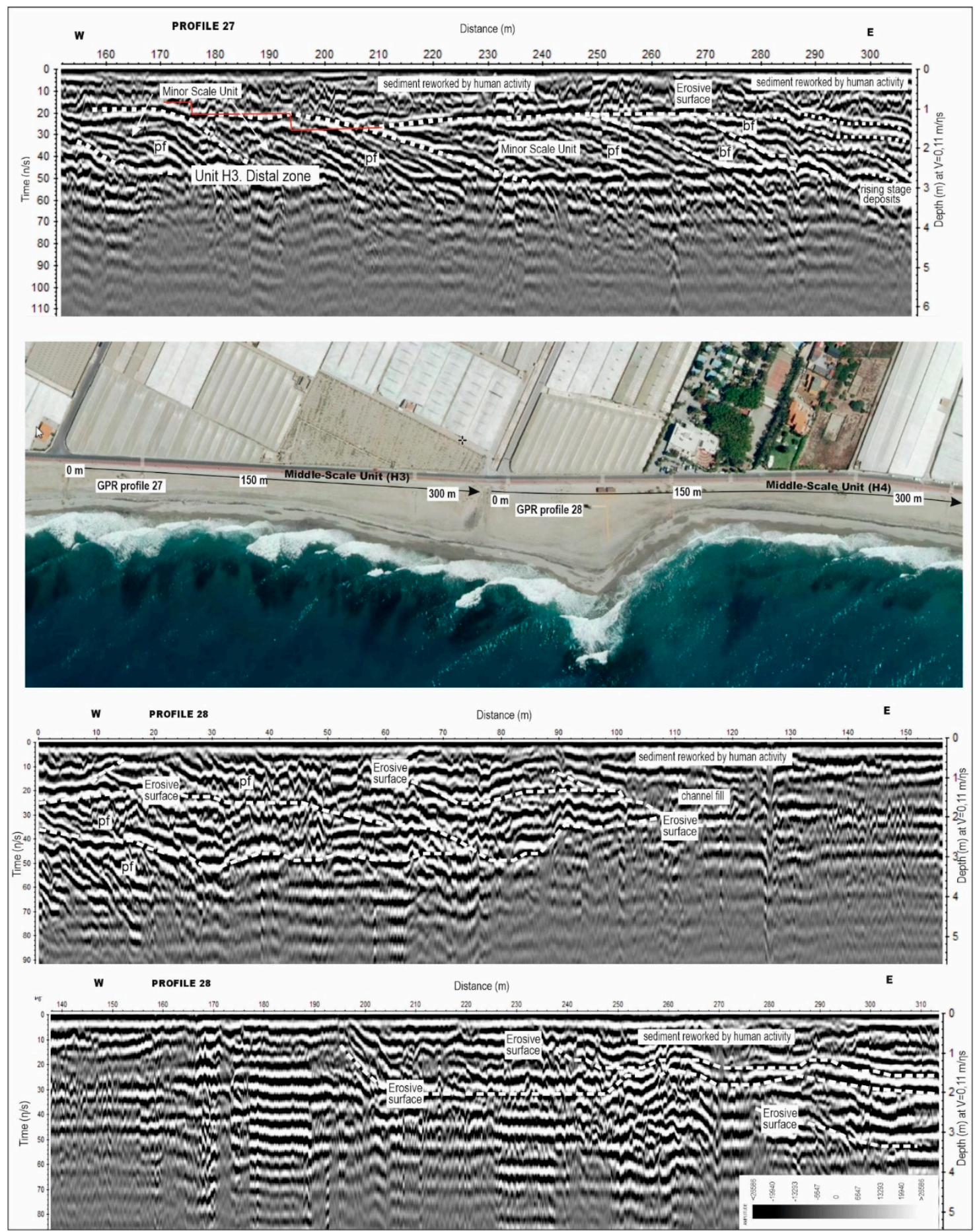

Figure 3. Radargrams obtained using a $250-\mathrm{MHz}$ antenna frequency in units 3 and 4 . The geometry and vertical position of the minor units indicate small sea-level falls (see red line). pf: prograding radar facies; bf: berm ridge radar facies.

The velocity of electromagnetic waves in these sediments was calculated using two methods. The first was an experimental method because the depth of the water table and the time required for the wave to arrive and be reflected (in the radargram) was measured in some of the wells near the coastline (Figure $1 b$ ). This velocity was confirmed in the data processing stage, by the second method, using the GPR processing software Reflexw, (specifically the option velocity adaptation, by fitting 
diffraction hyperbola). Both methods indicate a value of $0.11 \mathrm{~m} / \mathrm{ns}$, which is similar to those assessed in beach-ridge deposits in other sectors [21,28,29].

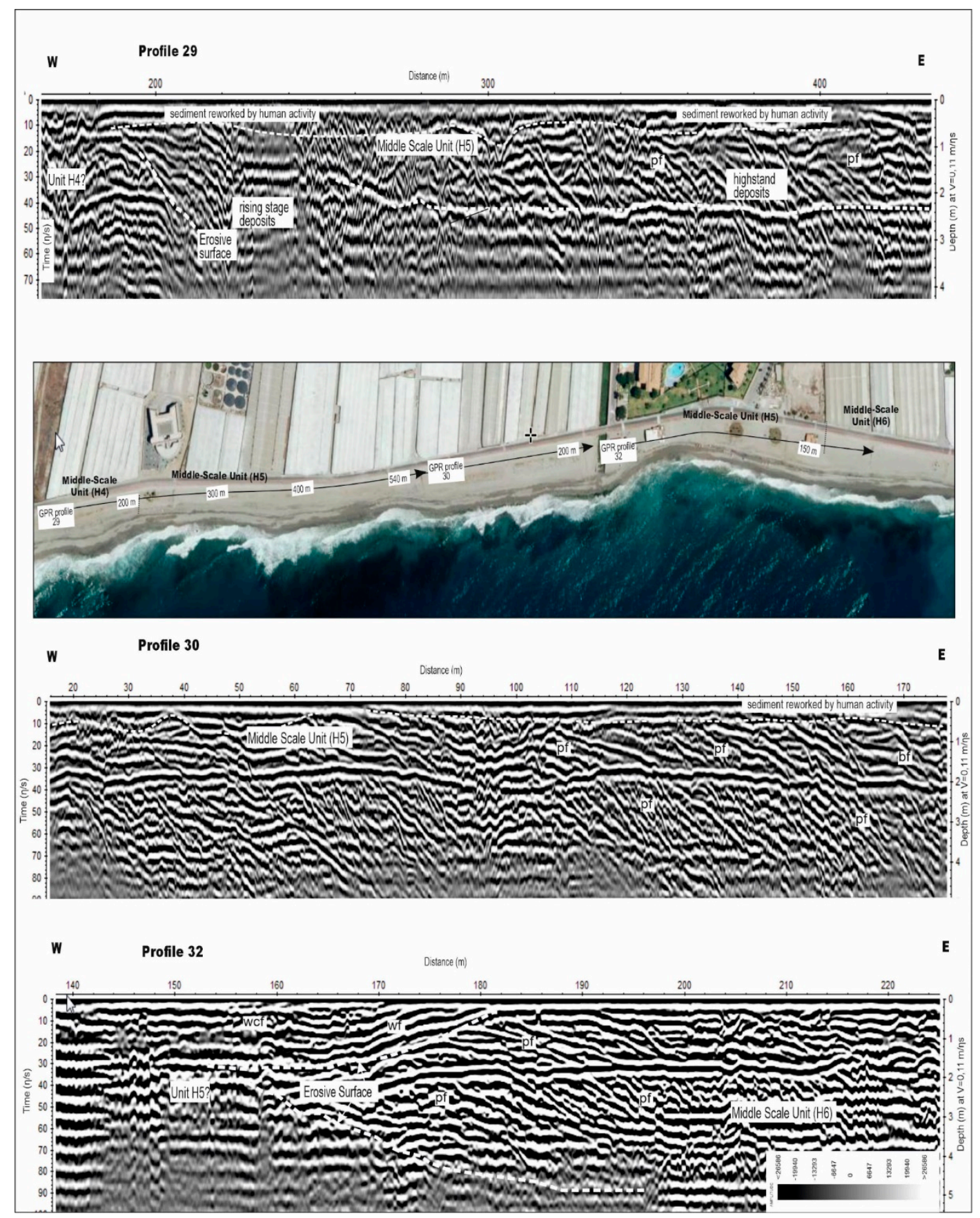

Figure 4. Radargrams obtained using a 250-MHz antenna frequency in units 5 and 6. pf: prograding radar facies; bf: berm ridge radar facies.wf: Washover fan radar facies. wcf: washover channel radar facies.

\section{Results and Discussion}

The profiles recorded using the 250-MHz antenna more clearly show the internal structures of the sedimentary bodies than those recorded using the $100-\mathrm{MHz}$ antenna. The penetration of radar electromagnetic waves can be quite variable, depending mostly on the electrical conductivity of the subsoil. High conductivity increases signal attenuation. Therefore, the freshwater-saltwater interface is inferred from the absence of reflected radar energy from the high-conductivity zones. This behavior 
allows for using the GPR for determining moisture content and its variation, flow processes and water quality [30]. Accordingly, profile 25, parallel to the coastline (Figure 2), has a reflector (from 3.2 to $3.6 \mathrm{~m}$ in depth) under which the signal weakens and is then lost, which is associated with the water table. The behaviour of the electromagnetic signal differs between profiles perpendicular to the coastline (see profile 2 in Figure 2): near the sea (in the extreme SW of profile 2), already in the saltwater zone, the signal fails to penetrate deeply. This shows the geometry of the freshwater-saltwater interface and is, therefore, highly useful for deducing saltwater intrusions in the continental zone. Additionally, in this profile, the erosive surface that separates the current beach and the Holocene progradational unit is detected.

In general, washed sands and gravels are the predominant lithologies in the sector, with little or no proportion in the pelitic matrix, which allows for electromagnetic wave transmission with low attenuation. Laterally, the presence of mud, deposited in enclosed and low-energy environments, can justify the signal attenuation [24].

Profile 25 is recorded in Unit H2 sensu Goy et al. [9]. The GPR data show the two stacked planar sets, approximately $1.5-2 \mathrm{~m}$ in power each, separated by reactivation surfaces between layers with different slopes. Figure 2 shows the interval between 500 and $600 \mathrm{~m}$ of profile 25 in which these structures are clearly visible. In this profile, a very gentle slope is detected on the stoss side, with higher slopes in the slipface zone. Inside these structures, the planar cross-bedding has a high angle in the lower body and a somewhat low angle in the upper position, migrating towards the southeast in all cases (toward the current coast). These sedimentary structures are likely equivalent to those described in the sedimentological exposure of beach ridge deposits $[1,2,18]$. These prograding beach facies (pf in Figures 2-4) have also been described in studies using GPR [19,24,25]. Towards the top, separated by an erosion surface, subhorizontal laminations likely correspond to the topset zone. Hyperbola associated with the roots of the current groundcover and with surface bioturbation are frequently found in the most superficial section of the profile.

These bodies of unit $\mathrm{H} 2$ are interpreted as southeastward-migrating coastal progradations, associated with a regressive period, equivalent to that described in other sectors of the coast in SE Spain [9] or in adjacent infralittoral zones [11,12]. Minor progradational units, which are deposited in topographically lower areas, are identified in the distal section of unit $\mathrm{H} 2$, from 660 to $760 \mathrm{~m}$ in profile 25: Figure 2 highlights the different vertical positions of two of these units, which highlights the decrease in accommodation space (at metre 700 in profile 25; Figure 2). These structures are prograding wedges characterised by downlap in the lower boundary and toplap in the upper boundary resulting from small sea-level falls (approximately $0.3-0.5 \mathrm{~m}$ ) and mild storm activity (some erosion tracks are identified). Locally, convex reflections, reaching inclinations from $0^{\circ}$ to $6^{\circ}$, have been interpreted as berm ridge facies (bf in Figure 2) sensu Montesa et al. [24]. On the top of this facies, the landward terminations grade downlap to onlap. Toward the sea, the bf facies are limited by an erosive surface (Figure 2).

The last section of the profile (from 750 to $790 \mathrm{~m}$ ) shows levels with high dips and high amplitudes intersecting the previous record, which could be interpreted as erosion tracks, equivalent to those described by Baumann et al. [31] in coastal environments. Bodies with onlap morphologies are deposited on these surfaces, which could correspond to a small event of rising stage deposits associated with the base of unit H3. Subsequently, from metre 785 of profile 25 , the electromagnetic signal is considerably attenuated. Therefore, the information provided is very scarce.

Profile 2, perpendicular to the previous profile, shows no cross-bedding, reflecting a virtually null dip. Towards the top and separated from an erosion surface, parallel laminations deeping seaward appear. Theses facies are interpreted as comprising sedimentary structures associated with the current foreshore (Figure 2).

Units $\mathrm{H} 3, \mathrm{H} 4, \mathrm{H} 5$ and $\mathrm{H} 6$ have morphologies equivalent to those described for unit $\mathrm{H} 2$. Figure 3 shows profile 27, which was recorded in the distal section of unit H3. As in the previous case, this profile highlights minor units with prograding wedges, which show downlap in the lower boundary and 
toplap in the upper boundary. These bodies could be associated, also in this case, with small regressive pulses at the end of unit H3 (from 150-250 m in Figure 3), with small sea-level falls, as shown by the stepwise decrease in elevation of these bodies on the radargram (Figure 3). This event could be correlated with the gap at the boundary of units H3 and H4 detected in other sectors of SE Spain [6,9], which dates to 2700 years BP according to those authors. In turn, this event could be correlated with one of the six major Holocene changes in vegetation identified by Jalut et al. [32] in the Mediterranean area, from southeastern France to southeastern Spain. These authors consider that this event corresponds to an aridification phase that occurred around $2850-1730 \mathrm{cal}$ BP. This arid episode was a regional response to more global climatic changes and determined the changes in the vegetation cover [32].

From metre 270 of profile 27, an erosional surface is detected that shows onlap, which could correspond to rising stage deposits in the base of unit $\mathrm{H} 4$. Berm ridges facies are interpreted (br in Figure 3). The top of the profile shows subhorizontal laminations, separated from unit H3-H4 by an erosional surface. This upper set corresponds to the topset zone. Hyperbola associated with the roots of the current groundcover are also frequently found.

Profile 28 records the first metres of unit H4 (Figure 3), including erosion tracks that are decametric in lateral length and metric in depth and which could correspond to large erosion surfaces associated with the base of channels, equivalent to those described in other coastal sectors [3,33,34], which could be related to increased strong intensity. These events could be correlated with those described in south Spain, both on the Mediterranean coast [9] and on the Atlantic coast [35] at approximately 2400 years BP. Beyond metre 100 in this profile, the electromagnetic signal lacks quality, showing considerable attenuation and disturbance that could be associated with an increase in the pelitic fraction, as described in similar sedimentary environments in other sectors [36].

The boundary between units H4 and H5 was drawn at metre 200 of profile 29 (Figure 4), showing a relatively high body, with erosion tracks, on which there are onlap deposits that are most likely rising stage deposits. This $\mathrm{H} 4 / \mathrm{H} 5$ boundary has been dated to 1900 years BP in other regions of the SE of Spain [9]. In the same profile, from metre 300, H5 progradational facies occur (pf in Figure 4) and show stacking of two planar sets separated by reactivation surfaces between layers with different slopes that are very similar to those of unit $\mathrm{H} 2$ and which could be interpreted as sedimentary structures typical of prograding beach ridges in a regressive context. These deposits could be associated with a stage of highstand deposits.

Morphologies similar to those described in the boundary between units $\mathrm{H} 4$ and $\mathrm{H} 5$ are also observed in the boundary between unit $\mathrm{H} 5$ and $\mathrm{H} 6$ in profile 32 from 150 to $170 \mathrm{~m}$ : unit $\mathrm{H} 6$ starts at approximately $160 \mathrm{~m}$ and has an internal structure equivalent to the previous structures. The morphology of its base shows erosion and stacking of bodies migrating from a relatively high area.

Sigmoidal landward dipping reflections have been detected in the H6 units (wf in Figure 4). In other regions, equivalent radar facies have been associated with the active migration of washover fans in the back-ridge environment $[24,25,30,37]$, in relation to storms or tsunami events. Laterally, sub-horizontal continuous reflections (landward dipping) appear (wcf in Figure 4). This facies has been interpreted as washover channel deposits, with the erosion and transference of sediments between the beach and the back-barrier domain $[24,30,33]$.

\section{Conclusions}

The GPR profiles recorded with the 250-MHz shielded antenna provide a good balance between penetration depth and resolution for these sandy coastal plain sediments. This method differentiates the southeastward progradation of sedimentary bodies with planar low-angle cross-bedding separated by both foreset and topset reactivation surfaces. These sedimentary structures are typical of prograding beach face deposits in a regressive context. The profile perpendicular to the coastline shows parallel laminations dipping towards the sea associated with the current foreshore.

Conversely, the water table level is identified at $3.5 \mathrm{~m}$ depth (varying slightly, depending on the sector), which matches the reflection present in the profiles and data measured directly in wells located 
in the area. Furthermore, the presence of saltwater in sediments near the coastline rapidly attenuates the signal, thereby preventing its penetration in the subsoil. Thus, the GPR is also a good tool to detect both water tables and saltwater intrusions in shallow aquifers.

In the GPR data, we identified a zone with strong erosional processes that can be correlated with an event 2400 years BP that marks the boundary between the two phases of progradation previously described by other authors both in the coastal plain and in infralittoral prograding wedges.

The GPR method can also be used to differentiate mid-scale units (H2, H3, H4 and H5). The distal part of each of the progradational units described in the coastal plain shows small regressive cycles represented by prograding wedges (minor scale units), deposited at lower elevations. These were likely the result of small sea-level falls that may be correlated with the periods of increased aridity described by other authors on the coast of SE Spain.

Highly advanced erosional surfaces, detected towards the base of the mid-scale units, could be associated with increases in storm intensity, combined with small sea level rises. Related to high-wave energy and the associated storm, washover deposit appears. These deposits are characterised by gently landward dipping, sub-parallel stratification.

Author Contributions: Conceptualization, J.R. Investigation, J.R., J.M. and M.C.H., Software, M.J.C. and R.M., Writing and review, J.R., J.M., M.H., M.J.C and R.M. All authors have read and agreed to the published version of the manuscript.

Funding: This research received no external funding.

Acknowledgments: The authors thank the CEACTEMA (University of Jaén) for the partial financing of this work.

Conflicts of Interest: The authors declare no conflict of interest.

\section{References}

1. Hine, A.C. Mechanism of development and resulting beach growth along a barrier spit complex. Sedimentology 1979, 26, 333-352. [CrossRef]

2. Carter RW, G. The morphodynamics of beach-ridge formation: Magilligan, northern Ireland. Mar. Geol. 1986, 73, 191-214. [CrossRef]

3. Tamura, T. Beach ridges and prograded beach deposits as palaeoenvironment records. Earth-Sci. Rev. 2012, 114, 279-297. [CrossRef]

4. Gouramanis, C.; Switzer, A.D.; Bristow, C.S.; Pham, D.T.; Mauz, B.; Hoang, Q.D.; Lam, D.D.; Lee, Y.S.; Soria, J.L.A.; Pile, J.; et al. Holocene evolution of the Chan May coastal embayment, central Vietnam: Changing coastal dynamics associated with decreasing rates of progradation possibly forced by mid- to late-Holocene sea-level changes. Geomorphology 2020. [CrossRef]

5. Zazo, C.; Goy, J.L.; Lario, J.; Silva, P.G. Littoral zone and rapid climatic changes during the last 20,000 years. The Iberia study case. Zeitschrift für Geomorphologie 1996, 102, 119-134.

6. Zazo, C.; Dabrio, C.J.; Goy, J.L.; Lario, J.; Cabero, A.; Silva, P.G.; Bardají, T.; Mercier, N.; Borja, F.; Roquero, E. The coastal archives of the last $15 \mathrm{ka}$ in the Atlantic-Mediterranean Spanish linkage area: Sea level and climatic changes. Quat. Int. 2008, 181, 72-87. [CrossRef]

7. Rodríguez-Ramírez, A.; Pérez-Asensio, J.N.; Santos, A.; Jiménez-Moreno, G.; Villarías-Robles, J.J; Mayoral, E.; Celestino-Pérez, S.; Cerrillo-Cuenca, E.; López-Sáez, J.A.; Ángel León, A.; et al. Atlantic extreme wave events during the last four millennia in the Guadalquivir estuary, SW Spain. Quat. Res. 2015, 83, 24-40. [CrossRef]

8. Zazo, C.; Dabrio, C.J.; Goy, J.L.; Bardají, T.; Ghaleb, B.; Lario, J.; Hoyos, M.; Hillaire-Marcel, C.I.; Sierro, F.; Flores, J.A.; et al. Cambios en la dinámica litoral y nivel del mar durante el Holoceno en el Sur de Iberia y Canarias Orientales. Geogaceta 1998, 20, 1679-1782.

9. Goy, J.L.; Zazo, C.; Dabrio, C.J. A beach-ridge progradation complex reflecting periodical sea-level and climate variability during the Holocene (Gulf of Almería, Western Mediterranean). Geomorphology 2003, 50, 251-268. [CrossRef]

10. Hernández-Molina, F.J.; Fernández-Salas, L.M.; Lobo, F.J.; Somoza, L.; Díaz del Río, V.; Alveirinho Dias, J.M. The infralittoral prograding wedge: A new large-scale progradational sedimentary body in shallowmarine environments. Geo-Mar. Lett. 2000, 20, 109-117. [CrossRef] 
11. Lobo, F.J.; Fernández-Salas, L.M.; Hernández-Molina, F.J.; González, R.; Dias, J.M.A.; Díaz del Río, V.; Somoza, L. Holocene highstand deposits in the Gulf of Cadiz, SW Iberian Peninsula: A high-resolution record of environmental changes. Mar. Geol. 2005, 219, 119-141. [CrossRef]

12. Fernández-Salas, L.M.; Dabrio, C.; Goy, J.L.; Del Río, V.D.; Zazo, C.; Lobo, F.J.; Sanz, J.L.; Lario, J. Land-sea correlation between Late Holocene coastal and infralittoral deposits in the SE Iberian Peninsula (Western Mediterranean). Geomorphology 2009, 104, 4-11. [CrossRef]

13. Lario, J.; Zazo, C.; Dabrio, C.J.; Somoza, L.; Goy, J.L.; Bardají, T.; Silva, P.G. Record of recent holocene sediment input on spit bar and deltas of South Spain. In Holocene Cycles: Climate, Sea Levels, and Sedimentation; Core, E., Ed.; 1. Coastal Researh: Fenwick Island, DE, USA, 1995; pp. 241-245.

14. Lario, J.; Zazo, C.; Goy, J.L. Fases de progradación y evolución morfosedimentaria de la flecha litoral de Calahonda (Granada) durante el Holoceno. Estud. Geol. 1999, 55, 247-250. [CrossRef]

15. Ortega-Sánchez, M.; Losada, M.A.; Baquerizo, A. On the development of large-scale cuspate features on a semi-reflective beach: Carchuna beach, Southern Spain. Mar. Geol. 2002, 198, 209-223. [CrossRef]

16. Ortega-Sánchez, M.; Lobo, F.J.; López-Ruiz, A.; Losada, M.A.; Fernández-Salas, L.M. The influence of shelf-indenting canyons and infralittoral prograding wedges on coastal morphology: The Carchuna system in Southern Spain. Mar.Geol. 2014, 347, 107-122. [CrossRef]

17. Aldaya, F. Mapa geológico y memoria explicativa de la hoja $n^{\circ}$ 20-44 (Albuñol) del mapa Geológico de España, escala 1:50,000; Instituto Geológico y Minero de España: Madrid, Spain, 1981.

18. Nordstrom, K.F.; Psuty, N.P.; Carter RW, G. (Eds.) Coastal Dunes: Form and Processes; John Wiley: Chichester, UK, 1990; p. 392.

19. Bristow, C.S.; Chroston, P.N.; Bailey, S.D. The structure and development of foredunes on a locally prograding coast: Insights from ground-penetrating radar surveys, Norfolk, UK. Sedimentology 2000, 47, 923-944. [CrossRef]

20. Neal, A. Ground-penetrating radar and its use in sedimentology: Principles, problems and progress. Earth-Sci. Rev. 2004, 66, 261-330. [CrossRef]

21. Gómez-Ortiz, D.; Martín-Crespo, T.; Rodríguez, I.; Sánchez, M.J.; Montoya, I. The internal structure of modern barchan dunes of the Ebro River Delta (Spain) from ground penetrating radar. J. Appl. Geophys. 2009, 68, 170-179. [CrossRef]

22. Clemmensen, L.B.; Nielsen, L. Internal architecture of a raised beach ridge system (Anholt, Denmark) resolved by ground-penetrating radar investigations. Sediment. Geol. 2010, 223, 281-290. [CrossRef]

23. Tamura, T.; Kodama, Y.; Bateman, M.D.; Saitoh, Y.; Watanabe, K.; Matsumoto, D.; Yamaguchi, N. Coastal barrier dune construction during sea-level highstands in MIS 3 and 5a on Tottori coast-line, Japan. Palaeogeogr. Palaeoclimatol. Palaeoecol. 2011, 308, 492-501. [CrossRef]

24. Montesa, A.; Bujaleskya, G.G.; Paredes, J.M. Geomorphology and internal architecture of Holocene sandy-gravel beach ridge plain and barrier spits at Río Chico area, Tierra del Fuego, Argentina. J. S. Am. Earth Sci. 2018, 18, 172-183. [CrossRef]

25. Berton, F.; Guedes CC, F.; Vesely, F.F.; Souza, M.C.; Angulo, R.J.; Rosa, M.L.; Bardoza, E.G. Quaternary coastal plains as reservoir analogs: Wave-dominated sand-body heterogeneity from outcrop and ground-penetrating radar, central Santos Basin, southeast Brazil. Sediment. Geol. 2019, 379, 97-113. [CrossRef]

26. Davis, J.L.; Annan, A.P. Ground-penetrating radar for high-resolution mapping of soil and rock stratigraphy. Geophys. Prospect. 1989, 37, 531-551. [CrossRef]

27. Annan, A.P. Ground Penetrating Radar: Principles, Procedures \& Applications; Sensors \& Software Incorporated: Mississauga, ON, Canada, 2003; p. 278.

28. Neal, A.; Richards, J.; Pye, K. Sedimentology of coarse-clastic beach-ridge deposits, Essex, southeast England. Sediment. Geol. 2003, 162, 167-198. [CrossRef]

29. Girardi, J.D.; Davis, D.M. Parabolic dune reactivation and migration at Napeague, NY, USA: Insights from aerial and GPR imagery. Geomorphology 2010, 114, 530-541. [CrossRef]

30. Muller, A.H. GPR study of pore water content and salinity in sand. Geophys. Prospect. 2001, 48, 63-85.

31. Baumann, J.; Dujardin, J.R.; Duringer, P.h.; Robin, N.; Schuster, M.; Bano, M. Internal Architecture of Foredunes and their Dynamics Resolved by GPR (Regneville Inlet, Normandy, France); EGU: Vienne, Austria, 2014; Volume 16.

32. Jalut, G.; Amat, A.E.; Bonnet, L.; Gauguelin, T.; Fontugne, M. Holocene climatic changes in the Western Mediterranean, from southeast France to south-east Spain. Palaeogeogr. Palaeoclimatol. Palaecol. 2000, 160, 255-290. [CrossRef] 
33. Dabrio, C.J. Sedimentary structures generated on the foreshore by migrating ridge and runnel systems on microtidal and mesotidal coasts on Spain. Sediment. Geol. 1982, 32, 141-151. [CrossRef]

34. Best, J.L.; Ashworth, P.J.; Bristow, C.S.; Roden, J. Three dimensional sedimentary architecture of a large, mid-channel sand braid bar, Jamuna River, Bangladesh. J. Sediment. Res. 2003, 73, 516-530. [CrossRef]

35. Zazo, C. Cambio climático y nivel del mar: La península ibérica en el contexto global. Cuaternario y Geomorfología 2006, 20, 115-130.

36. Pedersen, K.; Clemmensen, L.B. Unveiling past aeolian landscapes: A ground-penetrating radar survey of a Holocene coastal dunefield system, Thy, Denmark. Sediment. Geol. 2005, 177, 57-86. [CrossRef]

37. Switzer, A.D.; Bristow, C.h.S.; Jones, B.G. Investigation of large-scale washover of a small barrier system on the southeast Australian coast using ground penetrating radar. Sediment. Geol. 2006, 183, 145-156. [CrossRef]

(C) 2020 by the authors. Licensee MDPI, Basel, Switzerland. This article is an open access article distributed under the terms and conditions of the Creative Commons Attribution (CC BY) license (http://creativecommons.org/licenses/by/4.0/). 